\title{
Techniques and crops for efficient rooftop gardens in Bologna, Italy
}

\author{
Esther Sanyé-Mengual $^{1}$. Francesco Orsini ${ }^{2}$. Jordi Oliver-Solà ${ }^{1,3}$ • Joan Rieradevall ${ }^{1,4}$. \\ Juan Ignacio Montero ${ }^{1,5}$. Giorgio Gianquinto ${ }^{2}$
}

Accepted: 21 July 2015 /Published online: 7 September 2015

(C) INRA and Springer-Verlag France 2015

\begin{abstract}
Urban rooftop farming favours local food production. Although rooftop farming is perceived as a sustainable system, there is a lack of quantitative studies. There, we set up experiments in the community rooftop garden of a public housing building in Bologna, Italy, between 2012 and 2014. We grew lettuce, a leafy vegetable, using three techniques: nutrient film, floating hydroponic and soil cultivation. We also grew tomato, chilli pepper, eggplant, melon, watermelon on soils. Data was analysed by life cycle assessment for environmental and economic performance. Results reveal that the best techniques of lettuce cultivation to address global warming were floating in the summer, with 65-85\% less environmental impact per kilogran than nutrient film; and soil production in the winter, with 85-95\% less environmental impact. Furthermore, floating production was $25 \%$ cheaper in summer, and soil was $65 \%$ cheaper in winter, compared to the nutrient film technique. For soil production, eggplants and tomatoes showed the best environmental performances of about $74 \mathrm{~g} \mathrm{CO}_{2}$ per $\mathrm{kg}$. Eggplant production in soil was cheapest at $0.13 €$ per $\mathrm{kg}$.
\end{abstract}

Esther Sanyé-Mengual

esther.sanye@uab.cat

1 Sostenipra (ICTA-IRTA-Inèdit)- ICTA, Universitat Autònoma de Barcelona, Bellaterra, 08193 Barcelona, Spain

2 DIPSA, University of Bologna, Bologna, Italy

3 Inèdit Innovació, S.L. UAB Research Park, Cabrils, Barcelona, Spain

4 Chemical Engineering Department, Universitat Autònoma de Barcelona (UAB), Barcelona, Spain

5 IRTA, Cabrils, Barcelona, Spain
Keywords Urban agriculture $\cdot$ Local food · Building-integrated agriculture $\cdot$ Rooftop farming $\cdot$ Life cycle assessment $\cdot$ Agronomy $\cdot$ Hydroponics

\section{Introduction}

Urban rooftop farming is sprouting around cities driven by the growing interest in urban agriculture (Mok et al. 2013). Urban rooftop farming, a type of urban agriculture which is placed on the roofs of buildings, is growing in popularity in such a way that urban planning policy has started to include it, such as in New York City (New York City Council 2012). Rooftops have become a new resource thereby providing spaces for food cultivation in highly populated cities (Cerón-Palma et al. 2012; Specht et al. 2014; Thomaier et al. 2015). Among rooftop farming types, open-air rooftop farming is the most common (Thomaier et al. 2015) in contrast to more complex systems, such as rooftop greenhouses, which need a higher economic investment, or indoor farming, linked to a large energy demand (Germer et al. 2011; Specht et al. 2014). As part of urban agriculture, rooftop farming is linked to multiple sustainability benefits. Main opportunities are enhancing urban food security (Carney 2011), which is of particular interest in "food deserts" (Wrigley et al. 2004; McClintock 2011), boosting community empowerment, social inclusion and social cohesion processes (Howe and Wheeler 1999; Armstrong 2000; Lyson 2004; Lawson 2005; Teig et al. 2009; Carney 2011; Block et al. 2011; Guitart et al. 2012) and improving the environmental performance of new local food systems (e.g. reducing food transportation distances and food waste, enhancing urban biodiversity) (Howe and Wheeler 1999; McClintock 2010; Arosemena 2012; Guitart et al. 2012; Smith et al. 2013; Sanyé-Mengual et al. 2013). 
Open-air rooftop farming experiences are found worldwide and range from educational to commercial projects. "Food from the sky" is a community food project that takes advantage of the empty rooftop of a supermarket in North London (UK) with the aim of increasing the community food security (local action on Food 2012). In the Trent University (Peterborough, Canada), an educational rooftop garden is managed by students to produce food for the local campus restaurant (http://trentgardens.org/). The rooftop gardens in various Fairmont Hotels in Canada supply the kitchen demand with own-cultivated herbs, tomatoes, peas, beans and berries in beds and pots (http://www.fairmont.com/). The Eagle Street rooftop farm (http://rooftopfarms.org/) and the Brooklyn Grange (http://brooklyngrangefarm.com/) are the most wellknown rooftop farms of New York (USA), which combine local food production with education and social programs.

Research on these forms of urban agriculture has mainly focused on theoretical and agronomic aspects. Thomaier et al. (2015) reviewed current urban rooftop farming projects and discussed their contribution to a sustainable urban agriculture. Cerón-Palma et al. (2012) and Specht et al. (2014) provided a compilation of barriers and opportunities of urban rooftop farming based on focus group discussions and available literature, respectively. These studies highlighted the innovative potential of rooftop farming which can further develop urban agriculture and local food movements. Notwithstanding that rooftop farming can provide multiple sustainability benefits, the authors also pointed out the different barriers that these new systems might overcome for a large-scale implementation. Whittinghill et al. (2013) and Orsini et al. (2014) have performed agronomic studies of rooftop gardens to account for their productivity and their variability (e.g. different cultivation systems, seasonality) in Michigan (USA) and Bologna (Italy), respectively. Whittinghill et al. (2013) observed that green roof systems yielded worse than in-ground production although still showed a significant potential for local production. Experimental trials from Orsini et al. (2014) suggested that the production of leafy vegetables in floating systems is the most efficient, particularly in favourable seasons (spring, summer).

Notwithstanding the sustainable image of urban rooftop farming, only a few studies have focused on the quantification of their environmental, economic and social impacts. Astee and Kishnani (2010) analysed the potential domestic vegetable production of rooftop farming in Singapore, which could decrease the annual carbon footprint of the city up to $9 \mathrm{t}$ of $\mathrm{CO}_{2}$ emissions due to the reduced food imports. In the same line, Sanyé-Mengual et al. (2015b) evaluated the potential rooftop greenhouse implementation in industrial parks in Barcelona through a guide that combines geographic information systems and life cycle assessment, including a self-sufficiency and environmental assessment of local production. The implementation of rooftop greenhouses in the industrial park of
Zona Franca could satisfy the tomato demand of around 130,000 citizens of Barcelona in the short term. SanyéMengual et al. (2013) quantified the environmental benefits of the local supply chain of tomatoes produced in rooftop greenhouses in Barcelona (Spain) and contrasted with the conventional supply chain of tomatoes from Almeria (Spain). Sanyé-Mengual et al. (2015c) accounted for the environmental burdens of the structure of a rooftop greenhouse and compared it to a conventional greenhouse, since more resources are consumed for reinforcing rooftop greenhouses to meet legal requirements of buildings' technical codes. Tomato production in local rooftop greenhouses in Barcelona could be $33 \%$ more environmentally friendly, in terms of global warming, and $21 \%$ cheaper than conventional production in Almeria. However, the environmental and economic impacts of food production in open-air rooftop farming systems have not yet been studied. Furthermore, community rooftop gardens differ from other commercial systems (e.g. rooftop greenhouses) as they provide further social services (e.g. social inclusion), are managed by amateurs and are usually lowcost designs.

Besides, multiple cultivation systems can be used in urban rooftop farming (FAO 2013). Current projects involve from sophisticated growing systems (e.g. high-tech hydroponics) to soil-based crops cultivated in recycled containers (e.g. pallet cultivation). Among them, soil-based is the most commonly used technique (Thomaier et al. 2015). Even more, some rooftop farming experiences combine agriculture production with livestock, such as "The FARM:shop" in London (UK) which provides vegetables, fish and chicken products through an integrated rooftop-aquaponics system (local action on Food 2012). Some studies have dealt with the efficiency of different cultivation techniques from an agronomic perspective. Pennisi (2014) compared the crop yield of producing lettuce in rooftop farming, where floating production was more efficient than nutrient film technique and substrate (i.e. mix of perlite, coconut fibre and clay). At the city level, Grewal and Grewal (2012) quantified the potential production of urban agriculture, differentiating within cultivation scenarios, from conventional to hydroponic production. The study highlighted the larger food supply capacity of hydroponic systems due to a higher efficiency. In this sense, the quantification of the environmental burdens and economic costs of different cultivation systems for open-air farming may support design and decision-making processes.

The general aim of the paper is to assess urban rooftop farming from an environmental and economic point of view. The objectives of the study are to quantify both the environmental impacts and economic costs of a real case study by applying the life cycle assessment and life cycle costing methods. Specific objectives are, first, comparing three different cultivation techniques (nutrient film technique, floating, soil) for leafy vegetables production (lettuce); second, 
accounting for the burdens of soil production of multiple fruit vegetables (tomato, melon, watermelon, chili pepper and eggplant); and, finally, assessing the sensitivity of the results to the availability of re-used materials and the use intensity of the rooftop garden. A community rooftop garden in the city of Bologna is analysed for this purpose.

\section{Materials and methods}

The paper analyses the outputs of experimental crops performed in Bologna (Italy) by following the life cycle assessment (ISO 2006) and the life cycle costing (ISO 2008) methods to account for the environmental burdens and the economic cost of the systems.

\subsection{Experimental crops}

Experimental trials were performed from April 2012 to January 2014 on the rooftop of a public housing building in the city of Bologna (Italy). Bologna is a representative case study of Mediterranean cities, where year-round open-air rooftop farming practices can be performed due to favourable climatic conditions. The experimental crops were grown in a community garden implemented on the $250-\mathrm{m}^{2}$ terrace of the 10 th floor of the building. Three different cultivation systems were used in the trials: modified nutrient film technique, floating hydroponic and soil (illustrated in Fig. 1). Techniques were selected due to their use in current rooftop farming projects and their potential to be low-cost options for selfmanaged rooftop gardens. The modified nutrient film technique (Fig. 1a) was done on re-used polyvinyl chloride pipes, where leafy vegetables were placed in net pots to be in contact with the nutrient solution, which was recirculated and supported with additional irrigation. The floating system (Fig. 1b) consisted of a wooden container (made of re-used pallets and waterproofed with a plastic film), filled with the nutrient solution that was oxygenated with an aerator, where plants were grown on net pots placed on a floating polystyrene board. Soil production (Fig. 1c) was also done on wooden containers where plants were grown on commercial soil with compost and fertilizers. Tap water was used for irrigation in all the systems since rainwater harvesting system was not considered in the design.

Trials were performed for six crops including leafy and fruit vegetables: lettuce (Lactuca sativa L.), tomato (Solanum lycopersicum L.), melon (Cucumis melo L.), watermelon (Citrollus lanatus Thumb.), chili pepper (Capsicum annuum L.) and eggplant (Solanum melongena L.) (Fig. 1). The crops were chosen according to two criteria: crop production is feasible in open-air conditions in the study area and crops are representative of the Mediterranean diet. Leafy vegetables were cultivated in nutrient film technique, floating and soil, while fruit vegetables were only grown in soil. Crop cycles are indicated in Fig. 1 as days-after-transplanting values. Other vegetables although not included in this analysis were grown yearround in the garden. In particular, chicory and black cabbage were initially considered for assessing leafy vegetable production although were finally excluded due to low crop yield values.
Fig. 1 The experiment considered three different cultivation types for leafy vegetables: floating in wooden containers (1a), modified nutrient film technique in polyvinyl chloride pipes (1b) and soil in wooden containers (1c). Experiments were performed between 2012 and 2014 (2). The six crops followed different cycles: spring-summer, summer or autumn (2)
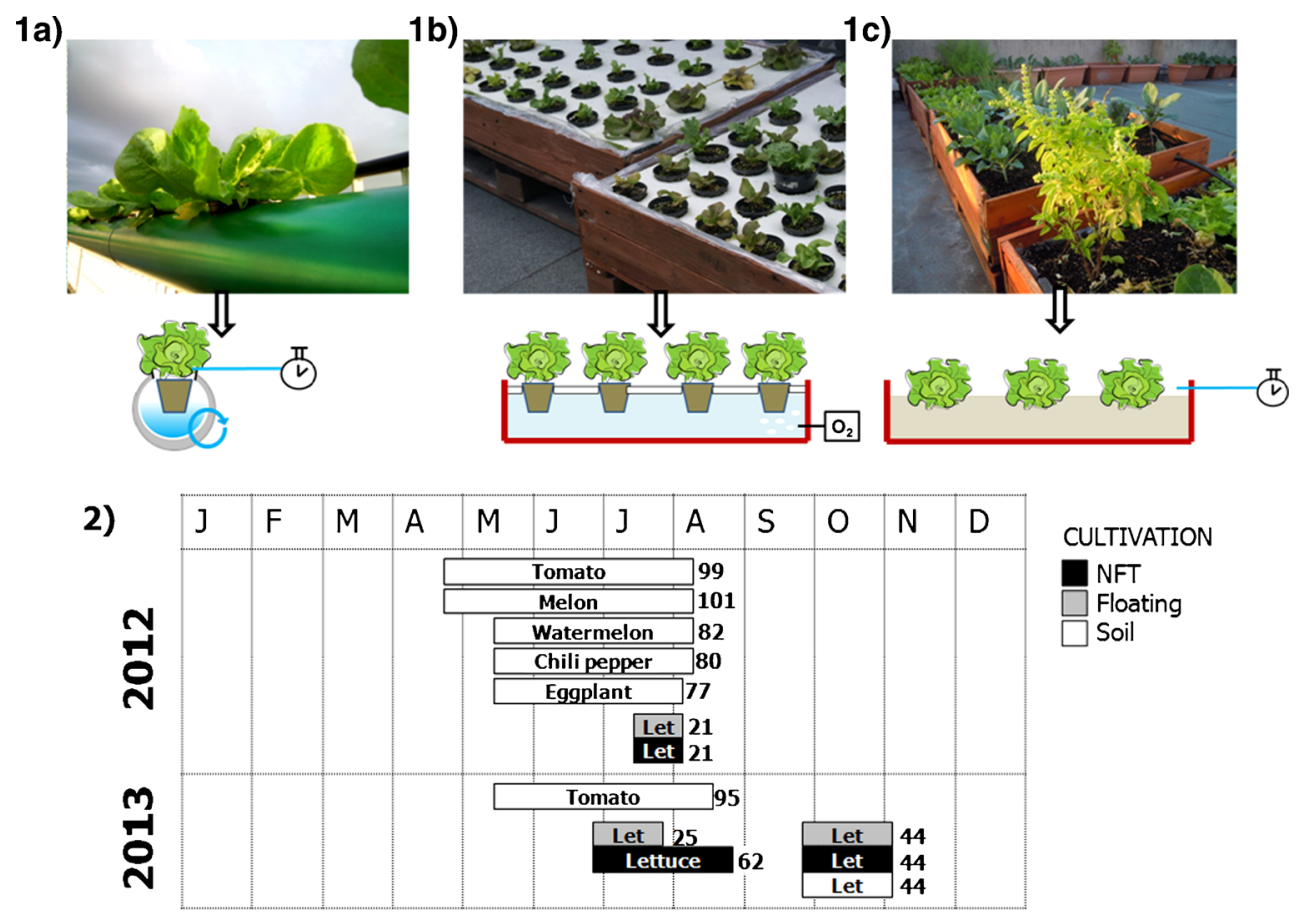


\subsection{Life cycle assessment}

This section describes the goal and scope, life cycle inventory and life cycle impact assessment steps followed in both life cycle assessment and life cycle costing analysis. Life cycle assessment is a standardized method to quantify the environmental impacts of systems, products or processes, defined by the ISO (2006) as "the compilation and evaluation of the inputs, outputs and the potential environmental impacts of a product system throughout its life cycle (i.e., consecutive and interlinked stages of a product system, from raw materials acquisition or generation from natural resources to final disposal)". The method follows four main stages: goal and scope definition, inventory, impact assessment and interpretation.

\subsubsection{Goal and scope}

As a self-managed system, the users of the case study directly harvest the produce they consume from the garden. Thus, the system is a cradle-to-consumer one, although other systems might include some distribution and retail stages (e.g. forprofit projects). In this paper, to make the production activity comparable to other systems, a cradle-to-farm gate is considered. Crop production thus includes the following life cycle stages: cultivation system (i.e. the life cycle impact of cultivation elements), auxiliary equipment (i.e. irrigation system), crop inputs (i.e. substrate, energy, water and fertilizers) and waste management. The analysis is performed for each individual crop (i.e. lettuce, tomato, melon, watermelon, chili pepper and eggplant), and the functional unit is $1 \mathrm{~kg}$ of product.

\subsubsection{Life cycle inventory}

Table 1 compiles the life cycle inventory of the three cultivation systems under assessment: nutrient film technique, floating and soil systems. With the aim of showing a picture of the current performance of the system, an attributional modelling is used in the inventory. Life cycle inventory data for the assessment is divided into cultivation system, auxiliary equipment and crop inputs. Cost data is shown in terms of unitary costs and per year of use.

(a) Cultivation systems and auxiliary equipment

The cultivation systems included in the analysis are modified nutrient film technique in polyvinyl chloride pipes, floating in wood container and soil in wood container (Fig. 1). Type and amount of materials are obtained from the experimental trials in Bologna and the designs detailed in Marchetti (2012). Wood containers are made of re-used pallets while former polyvinyl chloride pipes are used in the nutrient film technique system. When materials are reused, the environmental impacts of their extraction and manufacturing are excluded from the assessment as they belong to the former product. The auxiliary equipment includes all the elements related to the irrigation system required for each crop. Pumps and timer materials are excluded from the system boundaries due to the low repercussion per functional unit, based on a mass cut-off criterion. Inventory data is compiled in Table 1. Life cycle background data for material extraction, processing, transportation and electricity generation are obtained from ecoinvent 2.2. database (Swiss Center for Life Cycle Inventories 2010). Since the cultivation systems are used year-round for multiple crops, their impact is allocated for each crop product according to their crop cycle (indicated as days-after-transplanting values in Fig. 1).

(b) Crop inputs

Crop inputs depend on cultivation system and crop. First, water consumption is determined by cultivation system, crop, plant density and crop cycle. For soil cultivation, irrigation is of $11.7 \mathrm{~L} \mathrm{~m}^{-2}$ day $^{-1}$ for tomato and lettuce, 4.7 $\mathrm{L} \mathrm{m}^{-2}$ day $^{-1}$ for eggplant, $7.2 \mathrm{~L} \mathrm{~m}^{-2}$ day $^{-1}$ for chili pepper, $2.6 \mathrm{~L} \mathrm{~m}^{-2}$ day $^{-1}$ for melon and $3.7 \mathrm{~L} \mathrm{~m}^{-2}$ day $^{-1}$ for watermelon. For nutrient film technique, crops are irrigated with the nutrient solution through a recirculation system at a rate of $1.9 \mathrm{~L} \mathrm{~m}^{-2}$ day $^{-1}$ in autumn-winter cycles and of $3.9 \mathrm{~L} \mathrm{~m}^{-2}$ day $^{-1}$ in summer cycles. For floating cultivation, the container is filled with the nutrient solution and losses per evapotranspiration are replaced, resulting into a consumption of $1.3 \mathrm{~L} \mathrm{~m}^{-2}$ day $^{-1}$ in autumn-winter cycles and of $4 \mathrm{~L} \mathrm{~m}^{-2}$ day $^{-1}$ in summer cycles. The requirements for the irrigation timer, the recirculation pump (i.e. nutrient film technique) and the aerator (i.e. floating) are included in the energy consumption, which is calculated based on the power of each element and the time of use.

Fertilizers are supplied in a solid form in soil cultivation and as a nutrient solution in nutrient film technique and floating. For soil, $30 \mathrm{~g} \mathrm{~m}^{-2}$ year $^{-1}$ of N-P-K 15-5-20 with $2 \mathrm{~g} \mathrm{~m}^{-2}$ year $^{-1}$ of $\mathrm{MgO}$ and micronutrients are yearly supplied. For nutrient film technique and floating, the nutrient solution contains the following fertilizers: NPK $\left(80 \mathrm{mg} \mathrm{L}^{-1}\right), \mathrm{CaNO}_{3}$ (30 mg L ${ }^{-1}$ ) and $\mathrm{KNO}_{3}\left(40 \mathrm{mg} \mathrm{L}^{-1}\right)$. Soil cultivation is done on potting soil, where compost is added to regenerate it and to complete fertilization at a rate of $210 \mathrm{~g} \mathrm{~m}^{-2}$ of soil. Compost is made by the rooftop garden users by composting the biowaste from crops and their own organic waste. Plants in nutrient film technique and floating systems are placed on net pots with a mix of substrates: perlite (1/3), coconut fibre $(1 / 3)$ and expanded clay $(1 / 3)$. The manufacturing and transportation stages of the substrates are included in the assessment. All crops are pesticide-free. Seeds and young plants are excluded of the assessment due to the irrelevant contribution to the environmental and economic performances of the system. 
Table 1 Life cycle inventory data of the cultivation systems and crop inputs for modified nutrient film technique, floating and soil, for $1 \mathrm{~m}^{2}$ and a lifespan of 1 year

\begin{tabular}{|c|c|c|c|c|c|c|c|c|}
\hline & \multirow[t]{2}{*}{ Element } & \multirow[t]{2}{*}{ Material } & \multirow[t]{2}{*}{ Unit } & \multicolumn{3}{|l|}{ Cultivation systems } & \multicolumn{2}{|c|}{ Unitary cost } \\
\hline & & & & Nutrient film technique & Floating & Soil & & \\
\hline \multirow[t]{8}{*}{ Cultivation system } & Pallet & Wood & $\mathrm{kg}$ & - & 3.34 & 3.34 & 0 & $€ \mathrm{~kg}^{-1}$ \\
\hline & Screws & Steel & $\mathrm{kg}$ & - & 0.007 & 0.007 & 23.8 & $€ \mathrm{~kg}^{-1}$ \\
\hline & Angle iron & Iron & $\mathrm{kg}$ & - & 0.052 & 0.052 & 11.5 & $€ \mathrm{~kg}^{-1}$ \\
\hline & Wood agent & Varnish & $\mathrm{L}$ & - & 0.02 & 0.02 & 0.81 & $€ \mathrm{~L}^{-1}$ \\
\hline & Pipes & Polyvinylchloride (PVC) & $\mathrm{kg}$ & 1.62 & - & - & 0 & $€ \mathrm{~kg}^{-1}$ \\
\hline & PS board & Polystyrene (PS) & $\mathrm{kg}$ & - & 0.27 & - & 0.096 & $€ \mathrm{~kg}^{-1}$ \\
\hline & Construction & Electricity & $\mathrm{kWh}$ & - & 0.009 & 0.009 & 0.1539 & $€ \mathrm{kWh}^{-1}$ \\
\hline & Transport & $\operatorname{Van}, 3.5 \mathrm{t}$ & kgkm & 4.7 & 21.5 & 20.8 & 0.003 & $€ \mathrm{kgkm}^{-1}$ \\
\hline \multirow[t]{12}{*}{ Auxiliary equipment } & Sticks for support & Bamboo & $\mathrm{kg}$ & - & - & 0.18 & 0 & $€ \mathrm{~kg}^{-1}$ \\
\hline & Net pot & PVC & g & 25 & 46 & - & 0.074 & $€ \mathrm{~g}^{-1}$ \\
\hline & Water tank & PVC & g & 223.5 & - & - & 0.012 & $€ \mathrm{~g}^{-1}$ \\
\hline & Irrigation tubes & Polyethylene (PE) & $\mathrm{g}$ & 56.6 & - & 12 & 0.004 & $€ \mathrm{~g}^{-1}$ \\
\hline & Drippers & Polypropylene (PP) & g & 2.8 & - & 11.1 & 0.17 & $€ \mathrm{~g}^{-1}$ \\
\hline & Microtubes & PVC & g & 2.3 & - & 3.6 & 0.04 & $€ \mathrm{~g}^{-1}$ \\
\hline & Supporting stakes & PP & $\mathrm{g}$ & 6.8 & - & 2.7 & 0.03 & $€ \mathrm{~g}^{-1}$ \\
\hline & Barbed connectors & $\mathrm{PP}$ & $\mathrm{g}$ & 2.3 & - & 0.9 & 0.15 & $€ \mathrm{~g}^{-1}$ \\
\hline & Transport & Van, $3.5 \mathrm{t}$ & $\mathrm{kgkm}$ & 2.6 & 0.23 & 1.22 & 0.003 & 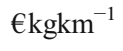 \\
\hline & Timer & - & - & $1 / 8.5$ & - & $1 / 36$ & 2.70 & $€$ \\
\hline & Aerator pump & - & - & - & $1 / 1.2$ & - & 6.62 & $€$ \\
\hline & Recirculation pump & - & - & $1 / 8.5$ & - & - & 3.47 & $€$ \\
\hline \multirow[t]{10}{*}{ Crop inputs } & Water & Tap water & $\mathrm{L} \mathrm{day}^{-1}$ & - & - & $2.6-11.7$ & 0.00153 & $€ \mathrm{~L}^{-1}$ \\
\hline & Electricity & Timer/Pump & $\mathrm{kWh}$ day $^{-1}$ & 0.0624 & 0.019 & 0.0033 & 0.1539 & $€ \mathrm{kWh}^{-1}$ \\
\hline & Fertilizers & Compost & g year $^{-1}$ & - & - & 210 & 0 & $€ \mathrm{~g}^{-1}$ \\
\hline & & NPK 15-5-20 & g year $^{-1}$ & - & - & 30 & 0.001 & $€ \mathrm{~g}^{-1}$ \\
\hline & Fertigation & Nutrient solution & $\mathrm{L} \mathrm{day}^{-1}$ & $1.96-3.92$ & $1.3-4$ & - & 0.003 & $€ L^{-1}$ \\
\hline & Substrate & Commercial soil & $\mathrm{kg}$ year $^{-1}$ & - & - & 2.09 & 0.045 & $€ \mathrm{~kg}^{-1}$ \\
\hline & & Perlite & $\mathrm{kg}$ crop $^{-1}$ & 0.27 & 0.49 & - & 0.493 & $€ \mathrm{~kg}^{-1}$ \\
\hline & & Coir & $\mathrm{kg}$ crop $^{-1}$ & 0.27 & 0.49 & - & 0.453 & $€ \mathrm{~kg}^{-1}$ \\
\hline & & Clay & $\mathrm{kg}$ crop $^{-1}$ & 0.27 & 0.49 & - & 0.267 & $€ \mathrm{~kg}^{-1}$ \\
\hline & Transport & Van, $3.5 \mathrm{t}$ & $\mathrm{kgkm}$ & 29.19 & 51.10 & 12.75 & 0.003 & $€ \mathrm{kgkm}^{-1}$ \\
\hline Waste management & Transport & Van, $3.5 \mathrm{t}$ & kgkm & 58.2 & 111.37 & 108.31 & 0.003 & $€ \mathrm{kgkm}^{-1}$ \\
\hline
\end{tabular}

Crop inputs are defined per year, crop or day, depending on cultivation systems. Water and electricity consumption for irrigations is shown per day since crop cycles are different and water demand depends on crop

Life cycle inventory data is obtained from the experimental trials, detailed in Orsini et al. (2014) and Marchetti (2012). Inventory data for home composting of green biowaste is obtained from Colón et al. (2010). Background data for the inventory is completed from the ecoinvent 2.2. database (Swiss Center for Life Cycle Inventories 2010) and the LCA Food database (Nielsen et al. 2003).

(c) Waste management

Waste management includes only the management of the elements of the cultivation materials at their end of life, since biomass is reintroduced in the crop cycle through composting. Cultivation materials (i.e. from cultivation system and auxiliary equipment) are $100 \%$ recyclable. As a result, their treatment is excluded from the analysis, and only their transportation is considered (recycling plants are located $30 \mathrm{~km}$ away from the site) (Ekvall and Tillman 1997).

(d) Cost data

Costs of the different materials and elements of the cultivation systems and auxiliary equipment are obtained from suppliers, as well as for substrate and fertilizers. Tap water cost is $0.00153 € \mathrm{~L}^{-1}$, according to Bologna's supplier (Gruppo Hera). Electricity cost is $0.1539 € \mathrm{kWh}^{-1}$ 
(EUROSTAT 2014). Transportation cost is $0.003 €$ $\mathrm{kgkm}^{-1}$, according to the transport type, consumption rate and current fuel prices. Material costs of re-used elements are considered as 0 , although the related transportation and construction requirements are accounted for.

\subsubsection{Sensitivity assessment}

Two variables are assessed as sensitivity parameters: the availability of re-used elements and the use intensity of the rooftop garden. First, although the current design is made of re-used materials, they can be also made with new pallets and pipes (e.g. lack of re-used pallets sources), particularly when re-used elements are unavailable. Thus, a "raw materials scenario" shows the potential increase in the resource consumption, considering that cultivation systems are made of new elements (i.e. raw materials) and multiple crops are done during the entire year (i.e. environmental impacts and costs of the cultivation system are allocated to the different crop periods).

Second, community and private gardens can be used seasonally, leading to a low use intensity (e.g. only summer crops) or can be year-round thereby combining autumnwinter and spring-summer crop cycles. A "low use intensity scenario" assumes that only one crop is done during the entire year, and therefore, the environmental impacts and costs of the cultivation system of the entire year are allocated to one crop.

\subsubsection{Life cycle impact assessment}

The environmental impact assessment is performed by applying the impact assessment stage. The SimaPro 7.3.3 software (PRé Consultants 2011) is used to conduct the life cycle impact assessment, which follows classification and characterisation steps determined as mandatory by the ISO 14044 regulation (ISO 2006). The impact assessment is carried out at the midpoint level, and methods applied are the ReCiPe (Goedkoop et al. 2009) and cumulative energy demand (Hischier et al. 2010). With respect to the ReCiPe, the hierarchical time perspective is considered, as recommended in the International life cycle database handbook (EC-JRC 2010). The environmental indicators include the global warming ( $\mathrm{kg} \mathrm{CO} \mathrm{CO}_{2}$ eq), the water depletion $\left(\mathrm{m}^{3}\right)$ and the cumulative energy demand (MJ). Besides, the human toxicity potential ( $\mathrm{kg}$ 1.4-DB eq.) is used to evaluate potential effects on human health. The human toxicity indicator relates the amount of emissions of toxic substances from the inventory to potential effect on human health, based on fate, exposure, effect and damage parameters of each substance (Goedkoop et al. 2009). Criteria for selecting the environmental indicators are the relevance in the topic of local food systems and agriculture (e.g. water depletion), the stakeholders' understanding of the indicators (e.g. global warming, energy consumption) and the representation of the different effects on human health (e.g. human toxicity). The life cycle costing assessment considers the cost of the systems, and results are shown through the total cost $(€)$ indicator.

\section{Results and discussion}

The environmental impacts and economic costs of crop production in open-air rooftop farming are shown and discussed in this section. First, an inter-vegetable comparison is performed to outline the global results. Second, the three cultivation techniques under assessment (soil, nutrient film technique, floating) are compared for the production of leafy vegetables. Third, the environmental performance and costs of soil production for multiple vegetables are discussed. Finally, the sensitivity of the results to the availability of re-used materials and the use intensity of the garden is assessed.

\subsection{Crop comparison}

Table 2 compiles the environmental and economic results for the production of fruit and leafy vegetables in the rooftop garden. Soil production of eggplant and tomato obtained the lowest environmental impact in global warming $(0.073 \pm$ $0.005 \mathrm{~kg} \mathrm{CO}_{2} \mathrm{eq} \mathrm{kg}^{-1}$, on average) human toxicity $(0.027 \pm$ $0.003 \mathrm{~kg}^{1-4 \mathrm{DBeq} \mathrm{kg}}{ }^{-1}$, on average) and energy consumption $\left(1.20 \pm 0.06 \mathrm{MJ} \mathrm{kg}^{-1}\right.$, on average), while eggplant was the cheapest crop $\left(0.17 € \mathrm{~kg}^{-1}\right)$. Lettuce production in floating technique was the most water efficient production $\left(<0.04 \mathrm{~m}^{3} \mathrm{~kg}^{-1}\right)$. On the contrary, lettuce production in nutrient film technique was the most expensive $\left(1.44 \pm 0.44 € \mathrm{~kg}^{-1}\right.$, on average) and the most impacting crop in global warming $\left(5.08 \pm 2.28 \mathrm{~kg} \mathrm{CO}_{2} \mathrm{eq} \mathrm{kg}^{-1}\right.$, on average), human toxicity (1.12 $\pm 0.52 \mathrm{~kg}^{1-4 \mathrm{DB}} \mathrm{eq} \mathrm{kg}^{-1}$, on average) and energy consumption (76.8 $\pm 34.0 \mathrm{MJ} \mathrm{kg}^{-1}$, on average), because of the large energy consumption of the recirculation pump and the low crop yield ( $1.3 \mathrm{~kg} \mathrm{~m}^{-2}$, on average). Finally, lettuce production in soil consumed the largest amount of water $\left(0.39 \mathrm{~m}^{3} \mathrm{~kg}^{-1}\right)$ since soil production is the least water efficient system and crop yield was low $\left(1.5 \mathrm{~kg} \mathrm{~m}^{-2}\right)$. When correlating these results with the agronomic data, relation to crop yield and crop period was moderately significant $\left(R^{2}>0.6\right)$. The lower the crop yield and the longer the crop period, the higher the environmental impacts and costs.

From the economic perspective, prices ranged between 0.13 and $1.95 € \mathrm{~kg}^{-1}$, and irrigation was the most contributing stage. Overall production costs of some crops (e.g. nutrient film technique and floating lettuce production) resulted larger than current market prices of conventional food products because of two main issues. First, given the 
importance of water consumption, urban gardeners pay a higher value for water since drinkable water is more expensive than water in rural agrarian areas. Second, one may consider that community rooftop farming provides further services than the food production itself. Thus, social services such as hobby, community building or education may be included in the cost-benefit assessment by accounting for the economic value of these positive externalities. Furthermore, one may note that the dedication of citizens in self-managed activities (e.g. community or private gardens) is not accounted for as a salary, as it is recreational time, although for-profit activities might account for the salary of gardeners. When comparing to prices of organic food production in the study area, rooftop lettuces were slightly cheaper $(0.67-1.95 €)$ than organic lettuces, the average price of which is between 2 and $3.50 €$ in the study area (Convertino 2014).

\subsection{Comparing cultivation techniques for leafy vegetables}

Figure 2 compares the environmental impacts and economic costs of lettuce production in nutrient film technique, floating and soil. Results strongly depended on the season. In summer cycles, floating production of lettuce showed the lowest environmental burdens and economic costs. In winter cycles, soil production was the most environmentally friendly and cheapest option, although floating production was the most water-efficient one.
For lettuce production in summer, floating production had an environmental impact per kilogram between 60 and $85 \%$ lower and costs were $25 \%$ cheaper than nutrient film technique. Causes of this divergence are the lower crop yield in nutrient film technique (46\% lower), the longer crop period (almost 2 times, on average), the electricity consumed by the recirculation pump and the higher water consumption in the nutrient film technique system.

For lettuce production in winter, soil was the more environmentally friendly and cheaper option, apart from the water depletion indicator where the floating technique consumed the lowest amount per kilogram $\left(0.04 \mathrm{~m}^{3} \mathrm{~kg}^{-1}\right)$. The water efficiency of the floating technique relies on the fact that the consumed amount of nutrient solution is fairly equal to that required by the plant. Then, floating has the smallest difference between the water supply and the evapotranspiration of the plant, as there is no drainage (e.g. in soil) and water evaporation is reduced. Electricity consumption for irrigation purposes was the lowest in soil production (i.e. timer), compared to the other systems where the use of electric devices is more intensive (i.e. recirculation pump, aerator). However, water consumption in soil production was 10 times larger because of a longer crop cycle, a lower crop yield $\left(1 \mathrm{~kg} \mathrm{~m}^{-2}\right.$, the lowest of the three techniques) and larger irrigation requirements per kilogram of product. In particular, soil production of leafy vegetables became a water inefficient system, since the irrigation rate $\left(1.3 \mathrm{~L} \mathrm{day}^{-1}\right.$ plant $\left.^{-1}\right)$ was the same as for some fruit vegetables (e.g. tomato). Thus, leafy vegetables

Table 2 Environmental and economic indicators for modified nutrient film technique, floating and soil production

\begin{tabular}{|c|c|c|c|c|c|}
\hline & $\begin{array}{l}\text { Global waming } \\
{\left[\mathrm{kg} \mathrm{CO}_{2} \text { eq, }\right]}\end{array}$ & $\begin{array}{l}\text { Human toxicity } \\
\text { [kg 1-4DB eq, }\end{array}$ & $\begin{array}{l}\text { Water depletion } \\
{\left[\mathrm{m}^{3}\right]}\end{array}$ & $\begin{array}{l}\text { Cumulative energy demand } \\
{[\mathrm{MJ}]}\end{array}$ & $\begin{array}{l}\text { Total cost } \\
{[€]}\end{array}$ \\
\hline \multicolumn{6}{|c|}{ Nutrient film technique } \\
\hline Lettuce-2012 & 2.51 & 0.542 & 0.0911 & 38.1 & 1.09 \\
\hline Lettuce-2013(1) & 4.88 & 1.09 & 0.196 & 73.3 & 1.36 \\
\hline Lettuce-2013(2) & 3.97 & 0.889 & 0.0855 & 60.5 & 1.95 \\
\hline \multicolumn{6}{|l|}{ Floating } \\
\hline Lettuce-2012 & 0.567 & 0.109 & 0.0395 & 9.37 & 0.67 \\
\hline Lettuce-2013(1) & 1.19 & 0.234 & 0.0904 & 19.6 & 1.42 \\
\hline Lettuce-2013(2) & 1.08 & 0.231 & 0.0393 & 18.6 & 1.29 \\
\hline \multicolumn{6}{|l|}{ Soil } \\
\hline Chili pepper & 0.174 & 0.06 .10 & 0.158 & 2.80 & 0.35 \\
\hline Eggplant & 0.0766 & 0.02 .41 & 0.0501 & 1.21 & 0.13 \\
\hline Lettuce-2013(2) & 0.323 & 0.123 & 0.389 & 5.15 & 0.74 \\
\hline Melon & 0.194 & 0.0553 & 0.0788 & 3.05 & 0.28 \\
\hline Tomato-2012 & 0.0753 & 0.0308 & 0.0980 & 1.26 & 0.18 \\
\hline Tomato-2013 & 0.0679 & 0.0277 & 0.0881 & 1.14 & 0.16 \\
\hline Watermelon & 0.133 & 0.0399 & 0.0719 & 2.09 & 0.21 \\
\hline
\end{tabular}

Results correspond to the functional unit of $1 \mathrm{~kg}$ of product per crop period. Indicators are global warming $\left(\mathrm{kg} \mathrm{CO}_{2}\right.$ eq), water depletion $\left(\mathrm{m}^{3}\right)$, cumulative energy demand (MJ), human toxicity (kg 1,4-DB eq.) and total cost $(€)$ 
were irrigated at a fruit vegetable rate although their water requirements are lower. This is caused by the simultaneous production of multiple vegetables (i.e. polyculture), while water requirements would be crop-specific in a monoculture design.

As a result, nutrient film technique is the worst option from both an environmental and economic perspective. Furthermore, notwithstanding the feasibility of using nutrient film technique crops in Bologna area, the use of this technique in the Mediterranean climate is limited to moderate temperatures. Major temperature changes can be produced in warmer areas (south Mediterranean) due to the low volume of nutrient solution, leading to a higher risk of plant mortality (FAO 2013).

For all the cultivation techniques (Fig. 3a), 'crop inputs' was the most contributing life cycle stage to the different environmental indicators $(>85 \%)$. In nutrient film technique production, $70 \%$ of the environmental impact was associated with the electricity consumed during irrigation, in particular for the recirculation of the nutrient solution. In floating production, the irrigation (nutrient solution and electricity) was responsible for $60 \%$ of the impact. In soil production, water accounted for the $75 \%$ of the overall impact. Furthermore, auxiliary equipment related to the irrigation system (e.g. timer, pump) made this life cycle stage the second most expensive one. A reduction of $50 \%$ of the lifespan of the irrigation equipment could increase the cost of production between 19 and $28 \%$ in floating production, although variability is lower when using the nutrient film technique (4\%) and soil production (1-2\%). Thus, improvements in the design of cultivation systems for leafy vegetables may focus on the irrigation requirements and the associated elements.

\subsection{Soil production of fruit vegetables}

Table 2 shows the environmental impact and economic cost of soil production of fruit vegetables. These crops had a global warming impact ranging from 68 to $194 \mathrm{~g}$ of $\mathrm{CO}_{2}$ eq., a human toxicity impact between 0.02 and $0.7 \mathrm{~kg} 1-4 \mathrm{DB}$ eq, a water depletion between 50 and $158 \mathrm{~L}$ and an energy consumption between 1.14 and 3.05 MJ. Total costs per kilogram varied from $0.17 €$ to $0.44 €$, being the crop inputs the major cost (52\%, on average) (Fig. 3a). The life cycle stage that contributed the most to the environmental indicators turned out to be the irrigation $(\approx 70 \%$ ), particularly in water depletion where it accounted for almost the $100 \%$. Within the irrigation system, the consumption of tap water was the main contributor to the water depletion $(\approx 52 \%)$ and economic cost $(\approx 80 \%)$, while the electricity consumed by the pump and the timer was the main cause (45-65\%) of the other environmental impacts (Fig. 3a).

Among fruit vegetables, the production of tomatoes and eggplants was the cheapest and most environmentally friendly crops. This trend is related to the high yield of these crops (8.2 $\mathrm{kg} \mathrm{m}^{-2}$ for eggplant and $13-14 \mathrm{~kg} \mathrm{~m}^{-2}$ for tomatoes),
Fig. 2 Environmental and economic indicators of soil, nutrient film technique and floating production of $1 \mathrm{~kg}$ of lettuce in summer and winter seasons

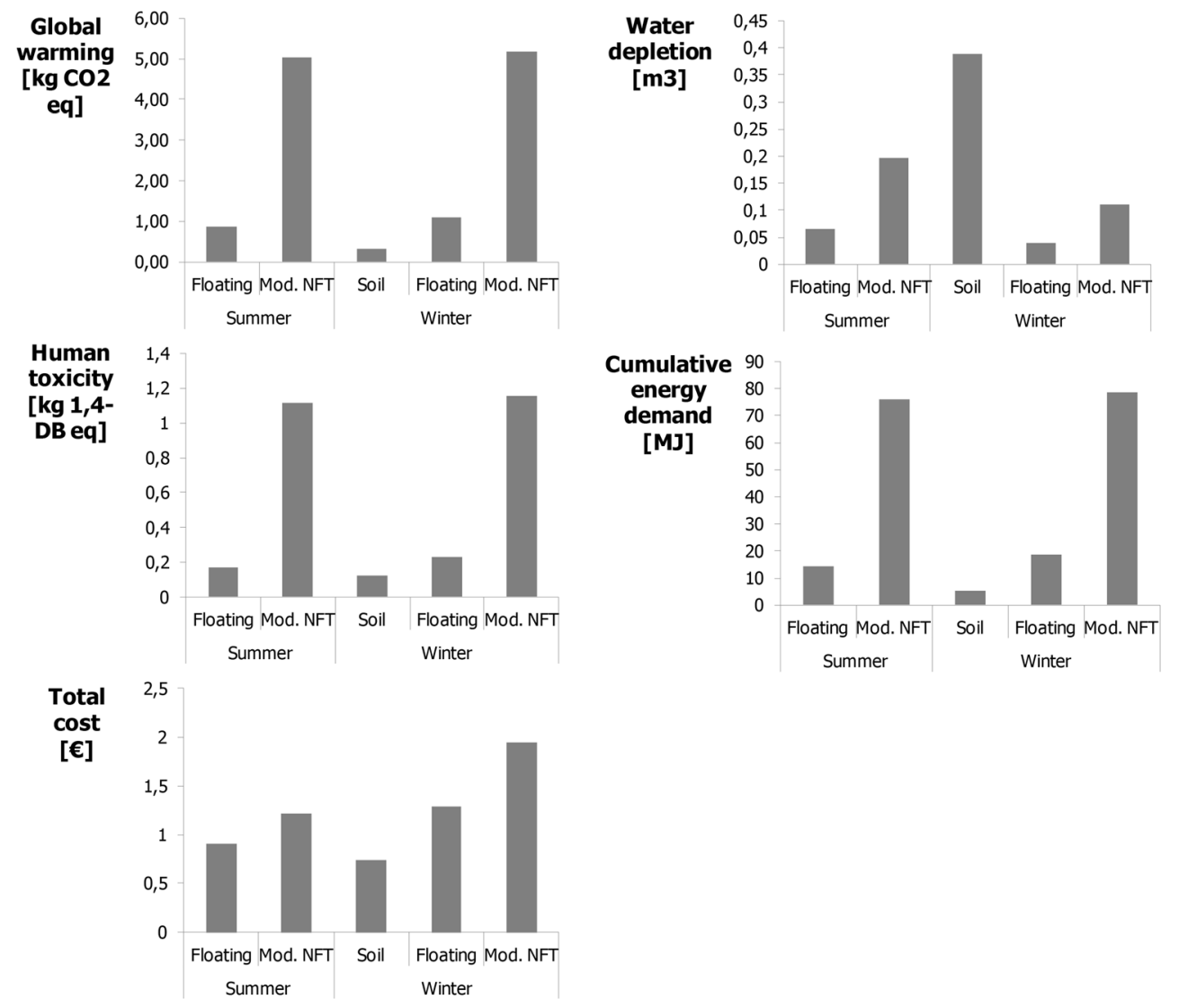


compared to the other crops with productivities lower than $5 \mathrm{~kg} \mathrm{~m}^{-2}$. On the other hand, chili pepper and melon were the crops that obtained the highest impact values, depending on the indicator (Table 2).

Since irrigation was the most contributing element, the use of rainwater harvesting systems may reduce the environmental impact. The substitution of the current tap water consumption with collected rainwater could reduce the global warming impact between 12 and $60 \%$, depending on the crop. When the amount of rainwater collected satisfies the whole crop water demand, water depletion could be avoided (i.e. become 0). Although there is available space in the rooftop garden for introducing raincollecting systems, the main constrain is actually given by the weight load of these reservoirs, which were not considered when the building was designed. On the other hand, if rainwater would be stored at ground level, supplementary energy to pump it to the 10th floor may be considered in the environmental and economic balance. However, for newly implemented buildings with integrated rooftop gardens, these constrains may be easily overtaken.

\subsection{Cultivation systems design: sensitivity assessment of availability of re-used materials and use intensity of the garden}

The sensitivity to the availability of re-used materials and the use intensity of the garden was analysed. Primarily, environmental impacts and economic costs of crop production in cultivation systems built with new elements (i.e. new pallets and new polyvinyl chloride pipes) were compared with the case study (i.e. re-used pallets and pipes). The environmental impact of a "raw materials scenario" was from 1.1- (nutrient film technique) to 1.8- (soil) folds higher than the reference scenario. The most sensitive indicator was the cumulative energy demand, which rose up to 3 times in soil production (data not shown).

The availability of re-usable elements in urban areas may be a limiting factor for the design of sustainable rooftop farming systems. In this case study, pallets and polyvinyl chloride pipes are the re-usable elements. First, pallets are growing in popularity due to their suitability for designing household and garden elements, such as furniture. To date, the used pallet
Fig. 3 a Distribution of the global warming potential and economic cost of lettuce and fruit vegetable production among life cycle stages; $\mathbf{b}$ carbon ecoefficiency (global warmingeconomic cost) of soil, floating and nutrient film technique production of multiple crops
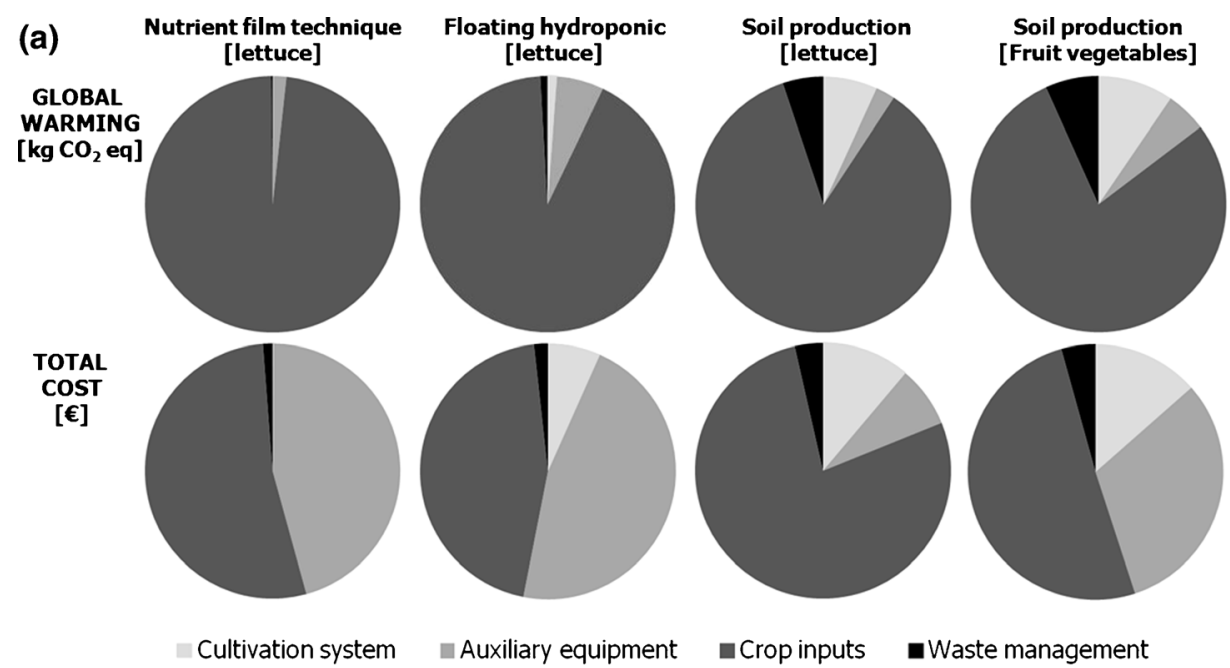

(b)

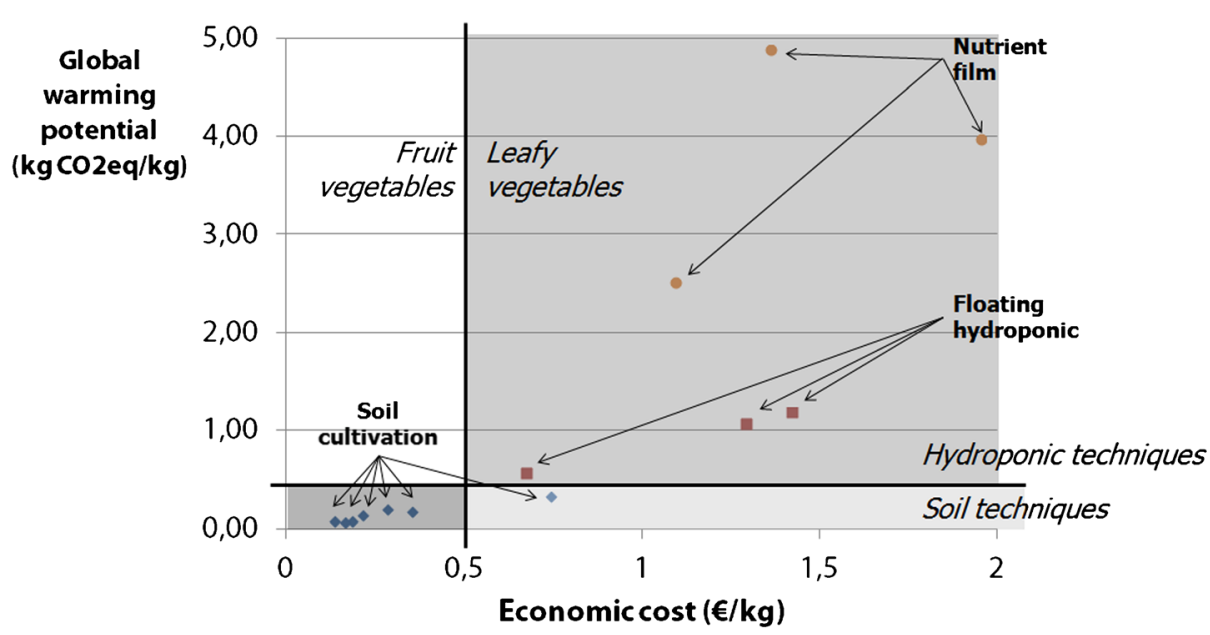


market is growing and availability seems guaranteed due to the worldwide use of these elements in the logistics sector. On the other hand, re-usable polyvinyl chloride pipes are less available for citizens, although their integration in a growing market of re-used products may become a way to manage the end-of-life of the current tap water distribution network. Moreover, polyvinyl chloride pipes have the lower global warming impact of the most common pipes used in urban water distribution networks ( Sanjuan-Delmás et al. 2014).

In the assessment, "re-use" is defined as the provision of a new use to an element after the completion of their primary function and, thus, the end of its designed lifespan. In this sense, the use of such elements for the design of rooftop gardens may not affect the market. However, bad practices could lead to the use of elements before the completion of their primary function and the integration into the garden design would affect the market, implying the production of an extra element to satisfy the incomplete function thereby increasing the resource consumption. In this case, the elements used in the cultivation system may be evaluated as raw materials rather than re-used ones in order to account for the consequent environmental burdens of their use.

Results of the year-round production systems (Table 2) were also compared to crop production in cultivation systems where only one crop is done per year (i.e. seasonal use). A "low use intensity scenario" showed an increase in the environmental impact of between 1.2- (nutrient film technique) and 2- (floating) folds (data not shown). Again, cumulative energy demand resulted to be the most sensitive indicator. Consistently, the impact associated with rooftop gardening can be highly affected by its use intensity. As a matter of fact, educational and training programs from public entities (e.g. municipality, associations and educational centres) are therein crucial in enabling citizens' knowledge on horticultural systems and their appropriate management. Skills on horticulture, crop production and crop planning may enhance the sustainability of community rooftop farming by leading to a yearround production (e.g. diversification of crops and crop cycles).

For lettuce (multiple crop cycles), the sensitivity to use intensity and availability of re-used materials was related to crop yield and crop period values. On nutrient film technique, the variation in the environmental impact of lettuce production was strictly related to the crop yield $\left(R^{2}>0.99\right)$. The higher the crop yield, the lower the variation in the environmental indicators. On the contrary, the sensitivity to the availability of re-used elements for the design depended on the crop period $\left(R^{2} \approx 0.8\right)$. The shorter the crop period, the lower the increase in the environmental indicators when using new materials. The same trends were found for lettuce production in floating technique.

\subsection{Recommendations for future rooftop farming design}

The assessment highlighted some recommendations for supporting decision-making processes of rooftop farming design and for the stakeholders involved in urban agriculture development. Results shed light on the identification of best practices in terms of cultivation techniques and crops. Figure $3 b$ displays the eco-efficiency of the different crops under assessment with regard to global warming. In the design of rooftop gardens, soil production and fruit vegetables might be prioritized to achieve higher levels of eco-efficiency. However, leafy production using the floating technique is recommended for areas where water scarcity is an environmental issue, as it is the most water-efficient option (Table 2). When implementing hydroponic systems (e.g. nutrient film technique, floating), attention might be paid to the minimization of the energy consumption (e.g. energy-efficient equipment) and the use of local and endogenous water sources (e.g. rainwater). Thus, designers and practitioners might combine different cultivation techniques depending on the specific conditions of the implementation area and the food requirements of the users.

Some limitations of polyculture systems were unraveled. In commercial initiatives, large areas for producing the same crop (i.e. monoculture practices) are resource-efficient and have high yields, such as in indoor farming or rooftop greenhouses. On the contrary, a community system for selfsufficiency is a polyculture system that combines different crops and types of vegetables (i.e. fruit and leafy) in order to satisfy the users' food demand and to minimize food waste. In the case study, the entire rooftop garden had the same design leading to a limitation of the production efficiency for some crops. Lettuce yielded at a lower rate due to a low plant density and had larger environmental burdens because of large water consumption, as both parameters were set for fruit vegetables. Thus, the design of polyculture gardens might consider the differentiation of multiple areas that have diverse design parameters according to the specific requirements.

The results from the case study provided further environmental and economic data of rooftop farming systems. A stakeholders' analysis regarding the implementation of rooftop farming in Barcelona ( Sanyé-Mengual et al. 2015a) identified that limited environmental benefits and economic advantages of rooftop systems were perceived as barriers. Thus, an improved knowledge can promote the overcoming of implementation barriers.

Finally, the production in urban gardens (both rooftop and soil-based) can be affected by shadows from other buildings. Johnson et al. (2015) quantified that decrease in crop yield of urban gardens due to light attenuation from building shadows was of $3.5 \%$ in a case study in Vancouver (Canada). In this sense, urban planners, designers and practitioners might consider this when selecting the emplacement of rooftop farming projects. 


\section{Conclusion}

The paper accounted for the environmental impacts and economic costs of crop production in a community rooftop farming in Bologna, thereby contributing to the sustainability assessment of urban agriculture from a quantitative approach. The environmental impacts and economic costs of the crops strongly depended on cultivation technique, crop yield and crop period. Soil production of eggplants and tomatoes, which had the highest crop yields, showed the best environmental and economic performance, except for water consumption where lettuce production in floating technique was the most efficient option. For leafy vegetables, floating technique and soil production were the best options, depending on the indicator and season.

As a community-managed system, the home-made compost and pesticides-free production allowed decreasing the chemical consumption in soil crops. The year-round polyculture design of the garden contributed to supply a diversified food demand of the neighbours, although a uniform design constrains the efficiency of some crops. Finally, the knowledge and training of rooftop garden users can affect the environmental and economic indicators, depending on their crop management efficiency and the final outputs of the rooftop farming.

Compared to other types of urban rooftop farming, the case study showed better environmental and economic performances than rooftop greenhouses. For instance, tomatoes produced in the open-air rooftop garden in Bologna had a global warming impact 3 times lower and economic cost 3.5 times lower than tomatoes produced in a pilot rooftop greenhouse in Barcelona, from a cradle-to-farm gate approach ( SanyéMengual et al. 2015b). Thus, rooftop gardens can become a way to promote urban agriculture in residential areas, where the investment in high-tech infrastructures (e.g. greenhouses, aquaponics) is more unlikely. Even more, residents can obtain cheap and environmentally friendly products that can boost the food security of urban areas (Orsini et al. 2014) and, in particular, can benefit certain marginal areas and stakeholders groups with little access to healthy food. However, further research on local food and urban agriculture systems is needed to evaluate the potential contribution of such systems to urban sustainability (Goldstein et al. 2014), to identify the role of rooftop farming and to assess the potentialities of the different forms of urban production (e.g. protected agriculture is less vulnerable to climatic variability).

Notwithstanding the potential benefits of open-air rooftop farming, the design of the cultivation system and the crop planning are crucial points to optimize the environmental and economic performance of these systems. Rooftop farming design may focus on the potential local resources that can be used in the construction stage, particularly on those elements that can have a second life in the garden through re-use (e.g. pallets, pipes, wheels). Moreover, the design may include different type of cultivation systems and crops, as fruit and leafy vegetables have different requirements. According to the results, we would recommend the use of soil techniques for fruit vegetables and winter cycles of leafy vegetables, while floating production would be interesting for summer crops of leafy vegetables. On the contrary, nutrient film technique would be the least recommended option, unless energy-efficient solutions are applied. Regarding management, crop planning may focus on selecting the vegetables (e.g. combination of fruit vegetables with higher crop yield and leafy vegetables) and establishing crop periods to diversify the production during spring-summer and fall-winter cycles, thereby producing year-round and reducing the environmental impacts and economic costs of crops. Further research may focus on integrating the social dimension in sustainability studies of rooftop farming by applying social indicators or including social services as positive externalities in the overall economic balance.

Acknowledgments This paper was written during a research visit of the corresponding author at the Department of Agricultural Sciences (DIPSA) at the Alma Mater Studiorium University of Bologna, financially supported - as a research travel scholarship - by the Spanish Ministerio de Educación, which is also awarding a research scholarship (AP2010-4044) to Esther Sanyé Mengual. Financial support for completing the article was also provided by the EU COST action Urban Agriculture Europe (TD 1106). Financial funding for the design and implementation of the activities on the rooftop garden were provided by Emilia Romagna Region, Bologna City Council and the EU (projects Hybrid Parks and HORTIS). Financial funding for urban rooftop farming research was also provided by the Spanish Ministerio de Economía y Competitividad (MINECO) within the research project "Agrourban sustainability through rooftop greenhouses. Ecoinnovation on residual flows of energy, water and CO2 for food production" (CTM2013-47067-C2-1$\mathrm{R})$.

\section{References}

Armstrong D (2000) A survey of community gardens in upstate New York: implications for health promotion and community development. Health Place 6:319-327

Arosemena G (2012) Urban agriculture: Spaces of cultivation for a sustainable city. Editorial Gustavo Gili (WD)

Astee L, Kishnani N (2010) Building integrated agriculture: utilising rooftops for sustainable food crop cultivation in Singapore. J Green Build 5:105-113

Block DR, Chávez N, Allen E, Ramirez D (2011) Food sovereignty, urban food access, and food activism: contemplating the connections through examples from Chicago. Agric Hum Values 29:203215. doi:10.1007/s10460-011-9336-8

Carney M (2011) Compounding crises of economic recession and food insecurity: a comparative study of three low-income communities in Santa Barbara County. Agric Hum Values 29:185-201. doi:10.1007/ s10460-011-9333-y

Cerón-Palma I, Sanyé-Mengual E, Oliver-Solà J et al (2012) Barriers and opportunities regarding the implementation of rooftop Eco. Greenhouses (RTEG) in Mediterranean cities of Europe. J Urban Technol 19:87-103. doi:10.1080/10630732.2012.717685 
Colón J, Martínez-Blanco J, Gabarrell X et al (2010) Environmental assessment of home composting. Resour Conserv Recycl 54:893904. doi:10.1016/j.resconrec.2010.01.008

Convertino L (2014) Orticoltura biologica e convenzionale: due realtà a confronto. Università degli studi di Padova

EC-JRC (2010) International reference life cycle data system (ILCD) handbook: General guide for Life cycle assessment - detailed guidance. Doi: $10.2788 / 38479$

Ekvall T, Tillman A-M (1997) Open-loop recycling: criteria for allocation procedures. Int J Life Cycle Assess 2:155-162. doi:10.1007/ BF02978810

EUROSTAT (2014) Energy statistics. http://epp.eurostat.ec.europa.eu/

FAO (2013) Good agricultural practices for greenhouse vegetable crops: principles for mediterranean climate areas. Food and Agriculture Organization of the United Nations, Rome

Local Action on Food (2012) A growing trade. A guide for community groups that want to grow and sell food in our towns and cities. Sustain: the alliance for better food and farming, London

Germer J, Sauerborn J, Asch F et al (2011) Skyfarming an ecological innovation to enhance global food security. J Verbr Lebnsm 6: 237-251. doi:10.1007/s00003-011-0691-6

Goedkoop M, Heijungs R, Huijbregts M et al (2009) ReCiPe 2008, a life cycle impact assessment method which comprises harmonised category indicators at the midpoint and the endpoint level; first edition report I: characterisation. Ministerie van VROM, Den Haag

Goldstein B, Birkved M, Hauschild M, Fernandez J (2014) Urban agricultural typologies and the need to quantify their potential to reduce a city's environmental "foodprint. World SB14, Barcelona, pp 24 31, 28/30th Oct. 2014

Grewal SS, Grewal PS (2012) Can cities become self-reliant in food? Cities 29:1-11

Guitart D, Pickering C, Byrne J (2012) Past results and future directions in urban community gardens research. Urban For Urban Green 11: 364-373. doi:10.1016/j.ufug.2012.06.007

Hischier R, Weidema B, Althaus $\mathrm{H}$ et al (2010) Implementation of life cycle impact assessment methods. Final report ecoinvent v2.2 No. 3. Swiss Centre for Life Cycle Inventories, Dübendorf

Howe J, Wheeler P (1999) Urban food growing: the experience of two UK cities. Sustain Dev 7:13-24. doi:10.1002/(SICI)10991719(199902)7:1<13::AID-SD100>3.0.CO;2-B

ISO (2006) ISO 14040: Environmental management - life cycle assessment - principles and framework

ISO (2008) ISO 15686-5: Buildings and constructed assets - sevice-life planning - part 5: life-cycle costing

Johnson MS, Lathuillière MJ, Tooke TR, Coops NC (2015) Attenuation of urban agricultural production potential and crop water footprint due to shading from buildings and trees. Environ Res Lett 10: 064007. doi:10.1088/1748-9326/10/6/064007

Lawson LJ (2005) City bountiful: a century of community gardening in America. University of California Press, Oakland

Lyson TA (2004) Civic agriculture: reconnecting farm, food, and community (civil society: historical and contemporary perspectives). Tufts

Marchetti L (2012) Above our heads, below the sky : a step-by- step procedure for creating and managing a soilless roof community garden. Alma Mater Studiorium Università di Bologna, Bologna

McClintock N (2010) Why farm the city? Theorizing urban agriculture through a lens of metabolic rift. Camb J Reg Econ Soc 3:191-207. doi: $10.1093 /$ cjres/rsq005

McClintock N (2011) From industrial garden to food desert: demarcated devalution in the flatlands of Oakland, California. In: Alkon A, Agyeman J (eds) Cultiv. food justice race, class, sustain. MIT Press, Cambridge, pp 89-120
Mok H-F, Williamson VG, Grove JR et al (2013) Strawberry fields forever? Urban agriculture in developed countries: a review. Agron Sustain Dev 24:21-43. doi:10.1007/s13593-013-0156-7

New York City Council (2012) Zone green text amendment (N 120132 ZRY)

Nielsen, Nielsen A, Weidema B, et al. (2003) LCA food data base

Orsini F, Gasperi D, Marchetti L et al (2014) Exploring the production capacity of rooftop gardens (RTGs) in urban agriculture: the potential impact on food and nutrition security, biodiversity and other ecosystem services in the city of Bologna. Food Secur 6:781-792. doi:10.1007/s12571-014-0389-6

Pennisi G (2014) Sistemi fuorisuolo per 1 ' orticoltura in città : casi studio nella città di Bologna. Alma Mater Studiorium Università di Bologna, Bologna

PRé Consultants (2011) SimaPro software version 7.3.3

Sanjuan-Delmás D, Petit-Boix A, Gasol CM et al (2014) Environmental assessment of drinking water transport and distribution network use phase for small to medium-sized municipalities in Spain. J Clean Prod. doi:10.1016/j.jclepro.2014.09.042

Sanyé-Mengual E, Cerón-Palma I, Oliver-Solà J et al (2013) Environmental analysis of the logistics of agricultural products from roof top greenhouses in Mediterranean urban areas. J Sci Food Agric 93:100-109. doi:10.1002/jsfa.5736

Sanyé-Mengual E, Anguelovski I, Oliver-Solà J et al (2015a) Resolving differing stakeholder perceptions of urban rooftop farming in Mediterranean cities : promoting food production as a driver for innovative forms of urban agriculture. Agric Hum Values. doi:10. 1007/s10460-015-9594-y

Sanyé-Mengual E, Cerón-Palma I, Oliver-Solà J et al (2015b) Integrating horticulture into cities: a guide for assessing the implementation potential of rooftop greenhouses (RTGs) in industrial and logistics parks. J Urban Technol 22:87-111, online

Sanyé-Mengual E, Oliver-Solà J, Montero JI, Rieradevall J (2015c) An environmental and economic life cycle assessment of rooftop greenhouse (RTG) implementation in Barcelona, Spain. Assessing new forms of urban agriculture from the greenhouse structure to the final product level. Int J Life Cycle Assess. doi:10.1007/s11367-0140836-9

Smith VM, Greene RB, Silbernagel J (2013) The social and spatial dynamics of community food production: a landscape approach to policy and program development. Landsc Ecol 28:1415-1426. doi:10.1007/s10980-013-9891-z

Specht K, Siebert R, Hartmann I et al (2014) Urban agriculture of the future: an overview of sustainability aspects of food production in and on buildings. Agric Hum Values 31:33-51. doi:10.1007/ s10460-013-9448-4

Swiss Center for Life Cycle Inventories (2010) Ecoinvent data v2.2

Teig E, Amulya J, Bardwell L et al (2009) Collective efficacy in Denver, Colorado: strengthening neighborhoods and health through community gardens. Health Place 15:1115-1122. doi:10.1016/j. healthplace.2009.06.003

Thomaier S, Specht K, Henckel D et al (2015) Farming in and on urban buildings: present practice and specific novelties of zero-acreage farming (ZFarming). Renew Agric Food Syst 30:43-54. doi:10. 1017/S1742170514000143

Whittinghill LJ, Rowe DB, Cregg BM (2013) Evaluation of vegetable production on extensive green roofs. Agroecol Sustain Food Syst 37:465-484. doi:10.1080/21683565.2012.756847

Wrigley N, Warm D, Margetts B, Lowe M (2004) The Leeds "food deserts" intervention study: what the focus groups reveal. Int J Retail Distrib Manag 32:123-136. doi:10.1108/ 09590550410521798 